\title{
Batik Tulis Paseban in Visual Perspective
}

\author{
Roni Nursyamsu ${ }^{1}$, Jerry Dounald $\mathbf{R}^{\mathbf{1}}$ and Rika Nugraha ${ }^{\mathbf{1}}$ \\ Department of Visual Communication Design Kuningan University, West Java \\ \{roninursyamsu@gmail.com\}
}

\begin{abstract}
Batik craft has long been developed in Indonesia, in terms of distribution, especially West Java. It has its own uniqueness both from the philosophical foundation, the types of ornamentation, the name of the ornament and the market share of its users. The spread of Sundanese batik based on the administrative region of West Java occurred grouping of motifs on batik works due to the visual style displayed. There is a coastal influence on Batik Cirebon, Indramayu and Kuningan. The types of ornaments found in the Sundanese Batik influence of coastal areas are Geometric Motifs, Human Motifs, Plant Motifs, Animal motifs and Mining motifs. Some researches on Sundanese Batik have been widely studied, but as an area that is influenced by coastal areas, Batik Kuningan has not yet received the full attention of researchers in particular. This research book on Kuningan Batik in Visual Perspective is an awakening of the sensitivity of the community that Kuningan has creativity, aesthetics and art in Batik Craft Art. Visual Literacy is a method carried out so that narrative and visual are formed as a reference for Batik Tulis Paseban in Visual Perspective
\end{abstract}

Keywords: Batik; Visual Perspective; Paseban

\section{Introduction}

Batik Tulis Paseban is a manifestation of Sundanese cultural artifact symbols that are born naturally from cultural values derived from the environment including archaeological thoughts of local thinking. Archeology of local thought includes religious thoughts, thoughts of courtesy (ethics), good and right thoughts (ethics), thoughts of kinship, thoughts of beauty (aesthetics). Paseban Batik Written was born from the thought of the three pattern according to the philosophy of Paseban, namely Tri Panca Tunggal. The meaning of Paseban is taken from the word Seba which means a gathering place, Tri which means three elements which are called Sir, Rasa, Pikir. Panca is five which means the five senses possessed by every human being and Single, which is one which means the oneness or oneness of the Creator.

The awareness of local cultural thought space has historically rationally lived in authentic evidence through a macrocosmic tripartite thought pattern. The three macrocosm patterns in Sundanese culture are the perfection of life, safety, welfare, prosperity. The pattern of the three macrocosms is the existence of the Three Worlds, namely the Upper World, namely the celestial world, the Middle World which is the human world and the Underworld namely the Earth. The spatial concept of Sundanese society is cosmologically triumvirate (triumvirate, triumvirate). In this order, it seeks to find the meaning of the world according to its existence, which concerns the freedom that contains all kinds of worlds with all their parts and aspects, so that nothing is excluded. The Sundanese people have a view of the parallels between the macrocosm and the microcosms, between the universe and the human world. 
The symbols of microcosm and macrocosm in this Sundanese philosophy are found in the form of motifs served through the art of building and the art of batik craftsmanship in Paseban. The concept of Sundanese society culturally in the life of the Sundanese people in Paseban Cigugur Kuningan with a philosophical meaning in each piece of Batik Tulis Paseban through an interpretation where interpretation itself can refer to a process of ongoing or interpretation of results. An interpretation can be a part of a presentation or portrayal of the modified information to comply with a set of specific symbols. The purpose of the interpretation usually is to improve understanding, gives an overview of the virtual state.

\section{Method}

Visual literacy includes the ability to read and construct a visual message. This means that visual literacy includes a person's ability to translate and interpret the meaning of a visual message and compile a meaningful visual message [3] They wanted to experience education - see it, hear it, and create it. Influenced by current culture, their learning modalities were overwhelmingly visual (Riddle: 2009) [4]. The presence of visual elements in today's teaching and learning is increasing as the integration of images and visual presentations with text in textbooks, instructional manuals, classroom presentations, and computer interfaces broadens (Benson, 1997; Branton, 1999; Dwyer as cited in Kleinman \& Dwyer, 1999) [4].

Based on the process, Jamieson [5] explains the formation of perception in the visual process which includes the following stages:

a. The Primary Stage: the optics of viewing

This process is the stage where a visualization or image is physically captured by the human eye.

b. The Secondary Stage: brain processing of visual information

As has been explained theoretically that the human brain can be divided into left and right brains, where this will in turn affect the thought process and stimulus processing experienced by a person.

c. The Third Arm: psychology and visual perception

At this stage, the images received by the eye and processed by the brain will be processed and interpreted based on individual experiences and backgrounds so that they can produce diverse perceptions for each person. The following shows the Visual Process according to Jamies H (2007).

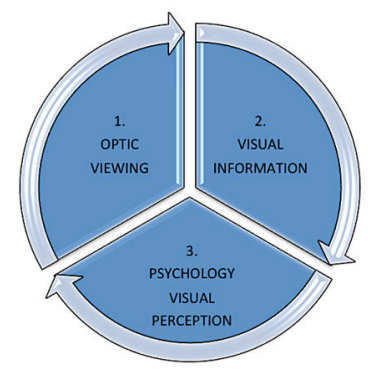

Fig 1. Visual Process 


\section{Result and Discussion}

The meaning of the Paseban Cigugur Batik motif as a whole has the meaning of the preservation of supernatural values as a human being, a picture of the majesty of nature as a reflection that nature and humans are closely related in life, self-awareness as a human being with passions, , similar to cosmic order . In this case Batik Tulis Paseban is a concept that states beauty belongs to God alone. Batik Tulis Paseban has more than 200 motifs, but with the recognition of various motifs that have in common, there are 7 Paseban Batik motifs that have been patented and have philosophical meanings in each of them. Likewise, with batik motifs. It has a wide variety of patterns and motives that arise from the imagination that describe dreams or hopes. Peeling batik cannot be separated from patterns and motifs, and it would be even more interesting of course also to talk with the symbols that surround the form [6].

Ornamental motifs are born from a desire to express something to others, whether it is the mind, hope, message, social strata, and also as a symbol of repelling disaster or as a guard or protector of safety for its occupants In addition, there are also ornaments that only function as decoration or edge decoration of an ornament image [7] In the visual literacy method approach to the Paseban Batik ornament can be displayed visually, such as the description of the motives below:

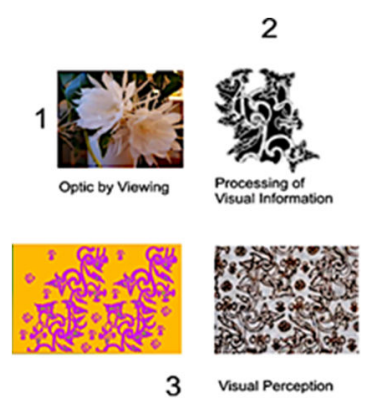

(a)

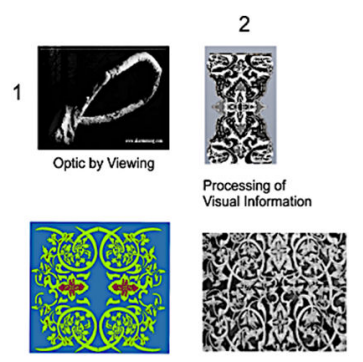

(b)

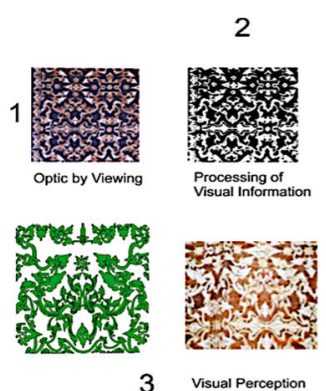

(c)

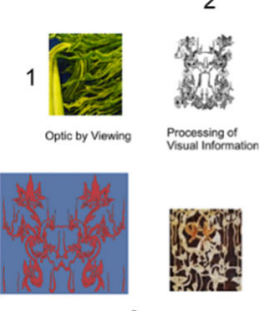

(d)
2

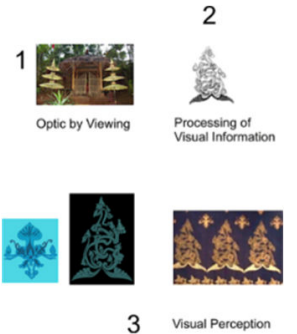

(e)

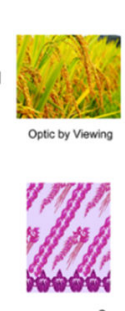

3

(1)

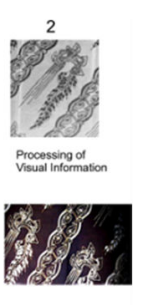

(f)

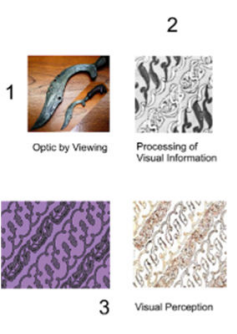

(g)

Fig. 2. Visual Process Batik Tulis Paseban Motifs: (a) Sekar Galuh Motif (b) Oyod Mingmang Motifs (c) Adu Manis Motifs (d) Mayang Segara Motifs (e) Geger Sunten Motifs (f) Rereng Pwah Aci Motifs (g) Rereng Kujang Motifs 


\section{Conclusion}

Paseban Batik motif is interpreted philosophically in the Kuningan community as reflected in everyday life with the use of batik cloth as a manifestation of gratitude to the creator. The role of information through visual literacy provides an understanding of verbal information into visual information for the wider community considering the importance of cultural preservation efforts for the present. Appropriate technology through visual literacy can provide added value to developing arts and cultures so that the meaning and philosophy of Batik Tulis Paseban through a visual literacy approach is more visually understood, compared to before through meaning and philosophy in the form of narrative without seeing the visual form of Batik Tulis Paseban itself.

\section{References}

[1] Jerry Dounald et al 2012 Balong International Journal Of Design 1 37-44

[2] Roni Nursyamsu 2013 Journal of English Education, 1(2),223-230

[3] Bamford,A 2010 The Grammar within the world of Interactive Media. Education Research Network Conference on Learning (8th, Spetses, Greece). 4-8 Juli 2001:1-10.

[4] Nurannisa et al 2017 Jurnal Pendidikan dan Pembelajaran Sekolah Dasar 1(2) 49

[5] Jamieson, H 2007 Visual Communication, More Than Meets the Eye. United Kingdom: Intellect Books, 15-18

[6] Sudarwanto, A. 2012. Rupa dan makna Simbolis Batik Motif Modang, Cemukiran. Jurnal Dewa Ruci, 8 (1), 107-123.

[7] Saragih,Daulat 2018 Pengembangan Tekstil Berbasis Motif dan Nilai Filosofis Ornamen Sumatera Utara.Panggung Jurnal Ilmiah Seni dan Budaya, 28 (2) 169. 